\title{
DECOMPOSITION OF GLIRICIDIA LEAVES: THE EFFECT OF PARTICLE SIZE OF LEAVES AND SOIL TEXTURE ON CARBON MINERALIZATION
}

\author{
BC Walpola $^{1 *}$ and KKIU Arunakumara ${ }^{2}$ \\ ${ }^{1}$ Department of Soil Science and ${ }^{2}$ Department of Crop Science, Faculty of Agriculture, University of Ruhuna, \\ Mapalana, Kamburupitiya, Sri Lanka
}

Accepted: $5^{\text {th }}$ February 2010

\begin{abstract}
Crop residues, as a reliable source of nutrients in many agro-ecosystems could minimize the dependency on commercial fertilizers. The particle size of crop residues is a matter of concern as it determines the accessibility of the substrate and nutrients in them to microbial attack. The present laboratory investigation was conducted to elucidate the effect of particle size of Gliricidia leaves $\left(S_{1} \leq 0.5 \mathrm{~mm}, \mathrm{~S}_{2}=4\right.$ $\mathrm{mm})$ and texture of soil $\left(T_{1}=\right.$ Sandy clay loam, $T_{2}=$ Loamy sand) on decomposition. The highest $C$ mineralization in Sandy clay loam soil and Loamy sand soil treated with the particle size of $\leq 0.5 \mathrm{~mm}$ were 134 and $241 \mathrm{mg} / \mathrm{kg}$ soil respectively. The corresponding figures for the particle size of $4 \mathrm{~mm}$ were 130 and $218 \mathrm{mg} / \mathrm{kg}$ soil respectively for Sandy clay loam soil and Loamy sand soil. Finer particles $(\leq 0.5$ $\mathrm{mm})$ have shown significantly higher $C$ mineralization than that of in coarse particles (4 mm) throughout the incubation except at day 2,7 and 14. Furthermore, $C$ mineralization in Loamy sand soil was significantly higher than that of in Sandy clay loam soil throughout the incubation. It could be concluded that $\mathrm{C}$ mineralization was significantly influenced by the texture of soil as well as the particle size of the plant residues.
\end{abstract}

Key words: Plant residues, Decomposition, C mineralization, Soil texture

\section{INTRODUCTION}

Declining soil fertility, a phenomenon that ultimately leads to soil degradation, has become a global issue in modern Agriculture (Lal 2001). Soil degradation refers to reduction in soil quality or reduction in the ability of the soil to perform a range of productive, environmental and habitat functions (Karlen et al. 1997; Scherr 1999; Lal 2001). In the context of soil degradation, a decline in soil fertility could be interpreted as the depletion of soil organic matter and plant nutrients (Syers 1997), water holding capacity, soil biomass, $\mathrm{pH}$, soil depth and aggregation (Scherr 1999). Thus degradation can have detrimental effects on soil physical, chemical and biological properties.

Soil fertility is closely related to soil organic matter (SOM) content (Tiessen et al. 1994), in particular, under low input conditions as in tropical small- holder Agriculture. Therefore, any effort to improve organic matter content of a soil is considered highly important in any sustainable system of Agriculture (Rodolfi and Zanchi 2002). Adding crop residues or prunings to the soil as mulch and green manure is believed to increase SOM (Young 1989). In tropical agricultural systems with limited access to fertilizers, plant residues are often used to meet the partial nutrient requirements of most of the crops. The benefits of green manures and crop residues include supply of plant nutrients (particularly $\mathrm{N}$ ) and increase in soil organic mattercontent and improvement in microbiological and physical properties of the soil (Yadvinder-Singh et al. 1991). The effective management of crop residues is thus an important aspect in sustainable cropping systems.

In addition to quality and quantity of plant residues, soil moisture and temperature, specific soil factors such as texture, mineralogy and acidity, biological activity and the presence of other nutrients are the main factors that determine rate of decomposition and subsequent nutrients release (Myers et al. 1994). It is generally believed that decomposition of organic residues is relatively slow in soils with higher clay contents, in particular, clays having higher exchange capacities. Furthermore, soils with coarse texture do have an edge over fine particles. However, according to Jensen (1994), clay minerals may inhibit mineralization during the first stage of decomposition; due to the protection of clay minerals on microbial biomass and metabolites formed during initial decomposition. Microbial activity is controlled by soil physical conditions such as moisture content, texture, compaction, temperature and oxygen; by chemical conditions such as substrate availability; and by biological conditions such as predatory or antagonistic organisms (Grant et al. 1993) 
Therefore the present study was undertaken to investigate; the effect of particle size of Gliricidia leaves on carbon mineralization during decomposition and the influence of soil texture on carbon mineralization during decomposition of Gliricidia leaves.

\section{MATERIALS AND METHODS}

\section{Climate and soil}

The experiment was conducted at the Faculty of Agriculture, University of Ruhuna, Mapalana, Kamburupitiya, Sri Lanka. According to the agroecological classification (Panabokke 1980), the region of investigation comes under agro-ecological region $\mathrm{WL}_{2}$ (Low country Wet zone). The climate of the area is tropical monsoonal (Panabokke 1980), with a warm wet period (April to June) and a relatively dry period (January to March). The area receives an annual rainfall of around $2,500 \mathrm{~mm}$. The distribution of rain is bi-model. Annual mean air temperature of the area is $22-30^{\circ} \mathrm{C}$ and the relative humidity is about $80 \%$. The soil used in this study belongs to Red Yellow Podzolic great soil group and is classified as Hapludults according to the USDA soil taxonomy (Mapa et al. 1998).

\section{Soil sampling}

Soil samples were collected randomly from the research farm of Faculty of Agriculture. Two areas of the farm were selected to represent two soil textural groups i.e. soil A- Sandy clay loam soil (clay 28 $\%$ ) and soil B- Loamy sand soil (clay $9 \%$ ). Sampling was done from $0-15 \mathrm{~cm}$ depth after removal of the surface litter. Samples were then mixed thoroughly in order to make composite samples. Physico-chemical characteristics of the soil were determined using standard methods (Table 1).

\section{Treatments}

Gliricidia leaves at same maturity stage were collected; oven dried $\left(72 \mathrm{~h}\right.$ at $\left.60^{\circ} \mathrm{C}\right)$ and ground to the size of $\leq 0.5 \mathrm{~mm}\left(\mathrm{~S}_{1}\right)$ and $4 \mathrm{~mm}\left(\mathrm{~S}_{2}\right)$. Sandy clay loam $\left(\mathrm{T}_{1}\right)$ and Loamy sand $\left(\mathrm{T}_{2}\right)$ were used to represent different types of textures. Soil without plant materials were served as the controls (C). Treatments were derived as $T_{1} C, T_{1} S_{1}, T_{1} S_{2}, T_{2} C, T_{2} S_{1}$, and $\mathrm{T}_{2} \mathrm{~S}_{2}$. Sub samples $(100 \mathrm{~g})$ of homogeneously mixed, air dried soil were placed in glass bottles. After adding water, samples were kept in the dark for two weeks prior to addition of plant materials. The moisture content of soil was routinely monitored and maintained at $50 \%$ of the field capacity (dry basis). The glass bottles were then opened and $216 \mathrm{mg}$ and $224 \mathrm{mg}$ of Gliricidia leaves were mixed thoroughly with Sandy clay loam and Loamy sand soils respectively. The amount of leaves added to soils was based on the mulch application rate which is equivalent to 5 tons of dry mat- ter per hectare, on the assumption that top $15 \mathrm{~cm}$ of soil in 1 ha contains $2.31 \times 10^{6} \mathrm{~kg}$ and $2.24 \times 10^{6} \mathrm{~kg}$ of soil respectively for Sandy clay loam and Loamy sand. The respective bulk densities of the soils are $1.54 \mathrm{~g} / \mathrm{cm}^{3}$ and $1.49 \mathrm{~g} / \mathrm{cm}^{3}$. Samples were then incubated in the dark at room temperature $\left(25 \pm 1^{\circ} \mathrm{C}\right)$. Constant moisture content of the soil was maintained throughout the incubation period.

\section{Carbon mineralization}

Soil samples were placed in gas-tight glass containers along with a vial contained $10 \mathrm{ml}$ of $1 \mathrm{M} \mathrm{NaOH}$ to trap $\mathrm{CO}_{2}$ and a vial of water to maintain humidity. Soils were incubated at room temperature (25 ${ }^{\circ} \mathrm{C}$ ) in the dark and $\mathrm{NaOH}$ traps were replaced 2, 5, $7,14,21,28,35,42,49,56,63$ and 70 days after the treatment. Unreacted alkali in the $\mathrm{NaOH}$ traps was titrated with $0.5 \mathrm{M} \mathrm{HCl}$ to determine $\mathrm{CO}_{2}-\mathrm{C}$ released from the soil (Anderson 1982).

\section{Statistical analysis}

Collected data were subjected to analysis of variance (ANOVA) for a Completely Randomized Design (CRD) with four replicates using SAS software (SAS Institute 1988). Least significant difference at $\mathrm{P} \leq 0.05$ was used to separate the means.

\section{RESULTS AND DISCUSSION}

The effect of particle size of the Gliricidia leaves on carbon mineralization in Sandy clay loam soil and Loamy sand soil is depicted in figure 1 and 2 . Carbon mineralization was found to be reduced after $14^{\text {th }}$ day of the incubation regardless the treatment. The highest values of mineralized carbon for Sandy clay loam soil and Loamy sand soil treated with the particle size of $\leq 0.5 \mathrm{~mm}$ were 134 and $241 \mathrm{mg} / \mathrm{kg}$ soil respectively. The corresponding figures for the particle size of $4 \mathrm{~mm}$ were 130 and 218 $\mathrm{mg} / \mathrm{kg}$ soil respectively for Sandy clay loam soil and Loamy sand soil. In contrast, steep reduction in $\mathrm{C}$ mineralization was observed in soil treated with finer particles $(\leq 0.5 \mathrm{~mm})$ during the first 7 days of incubation. According to the results, finer particles $(\leq 0.5 \mathrm{~mm})$ have shown significantly $(\mathrm{P} \leq 0.05)$ higher $\mathrm{C}$ mineralization than that of in coarse particles $(4 \mathrm{~mm})$ throughout the incubation. Furthermore, $\mathrm{C}$ mineralization in Loamy sand soil was found to be significantly $(\mathrm{P} \leq 0.05)$ higher than that of in Sandy clay loam soil indicating that $\mathrm{C}$ mineralization was significantly $(\mathrm{P} \leq 0.05)$ influenced by the texture of soil also. However, exceptions could be observed at 7, 42 and 56 days of incubation. Though $\mathrm{C}$ mineralization at $56^{\text {th }}$ day of incubation was comparatively high, it was not significantly ( $P$ $\leq 0.05$ ) affected by either the texture of soil or particle size of the leaves. 

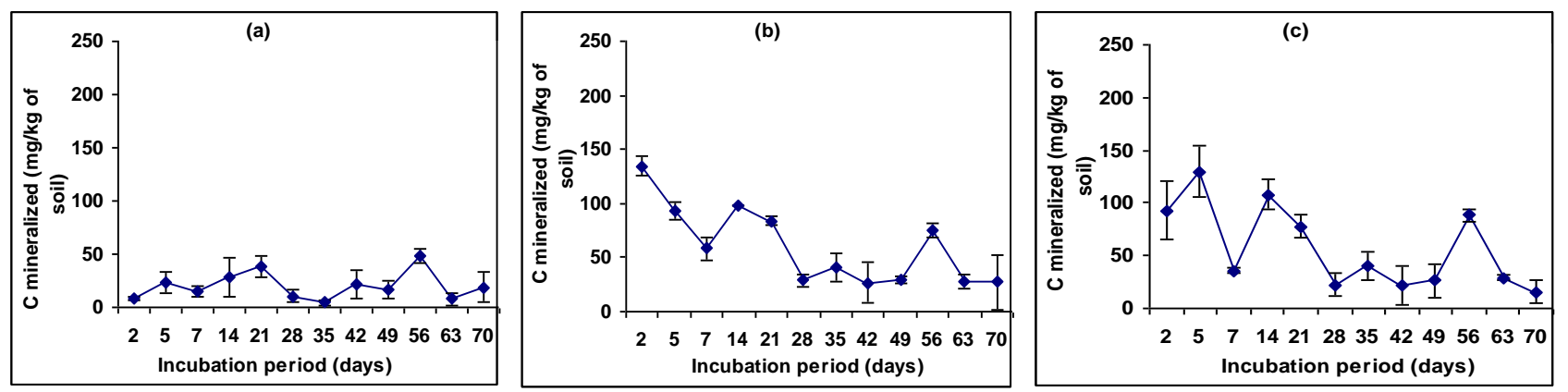

Figure 1. Carbon mineralization of sandy clay loam Soil $\left(T_{1}\right)$ amended with Gliricidia leaves; (a) $T_{1} C$ (without Gliricidia leaves), (b) $T_{1} S_{1}$ (treated with Gliricidia leaves of $\leq 0.5 \mathrm{~mm}$ particle size), (c) $T_{1} S_{2}$ (treated with Gliricidia leaves of $4 \mathrm{~mm}$ particle size). Values given here are the means $(\mathrm{n}=4) \pm$ standard deviation.
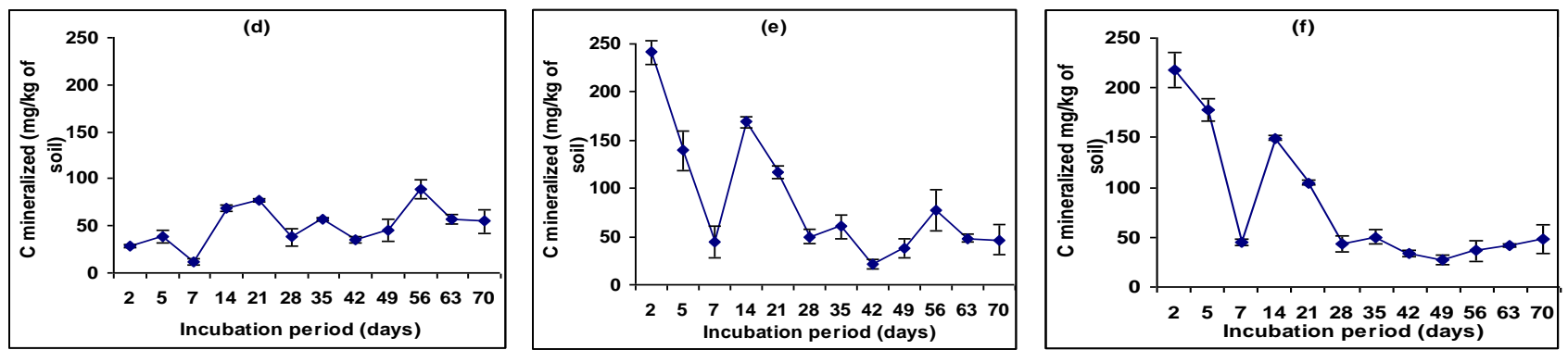

Figure 2. Carbon mineralization of the Loamy sand soil $\left(T_{2}\right)$ amended with Gliricidia leaves; (d) $T_{2} C$ (without Gliricidia leaves), (e) $T_{2} S_{1}$ treated with Gliricidia leaves of $\leq 0.5 \mathrm{~mm}$ particle size and (f) $T_{2} S_{2}$ treated with Gliricidia leaves $4 \mathrm{~mm}$ particle size. Values given here are the means $(n=4) \pm$ standard deviation.

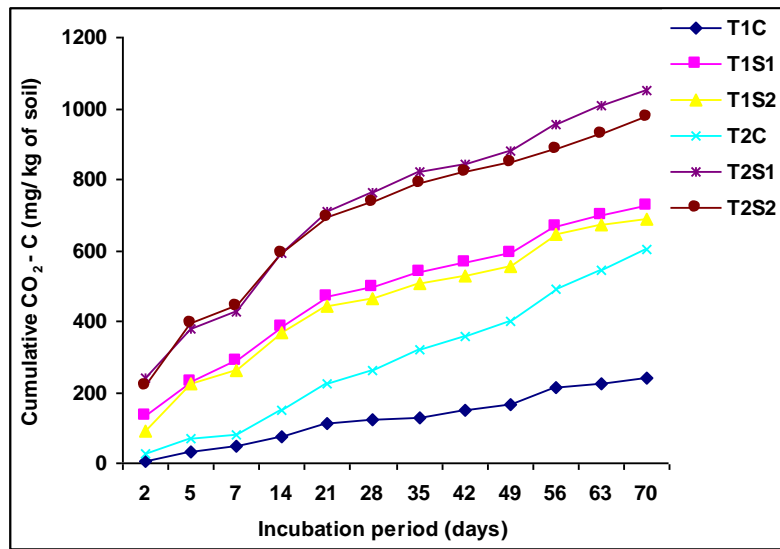

Figure 3. Cumulative $\mathrm{CO}_{2}-\mathrm{C}(\mathrm{mg} / \mathrm{kg}$ soil) evolution of the soil amended with various sized particles of Gliricidia leaves $\left(T_{1}=\right.$ Sandy clay loam, $T_{2}=$ Loamy sand, $\mathrm{C}=$ control, $\mathrm{S}_{1}=$ Gliricidia leaves of $\leq 0.5 \mathrm{~mm}$ particle size and $S_{2}=$ Gliricidia leaves of $4 \mathrm{~mm}$ particle size).

The particle size of crop residues is a matter of concern as it determines the surface area available for the colonization of the soil microbes. Decreasing particle size increases the exchange of water, nutrients and oxygen, thus speeds up the colonization of soil microbes (Angers and Recous 1997). Greater accessibility of the substrate and nutrients in them to microbial attack could thus result in rapid mineralization as observed from the present findings with finer plant residues. Peter et al. (2001) have also reported that particle size of the crop residues influences the activities of microbial population in soil and the stages of the decomposition.

The particle size of plant materials acts as a determining factor of recalcitrant substances (Vanlauwe et al. 1997). As finer particles possess a greater surface area than of coarse particles, they could effectively strengthen the contact between soil (water films) and residues (Angers and Recous 1997). However, decomposition of coarse plant materials could also be high in soils with low porosity, smaller aggregates and a fine texture

Table 1. Some important physico-chemical properties of soil

Soil A - Sandy clay loam soil; Soil B - Loamy sand soil

\begin{tabular}{|c|c|c|c|}
\hline Property & Soil A & Soil B & Analytical Method \\
\hline Soil texture & $\begin{array}{l}\text { Sand }-59 \% \\
\text { Silt }-12 \% \\
\text { Clay }-28 \%\end{array}$ & $\begin{array}{c}\text { Sand }-79 \% \\
\text { Silt }-11 \% \\
\text { Clay }-09 \%\end{array}$ & $\begin{array}{l}\text { Sedimentation } \\
\text { and Decantation } \\
\text { method }\end{array}$ \\
\hline $\begin{array}{l}\text { Organic C } \\
(\%)\end{array}$ & 0.50 & 0.72 & $\begin{array}{l}\text { Wet oxidation } \\
\text { method }\end{array}$ \\
\hline Total N (\%) & 0.21 & 0.13 & $\begin{array}{l}\text { Micro Kjeldhal } \\
\text { method }\end{array}$ \\
\hline $\begin{array}{l}\text { Borax P } \\
\text { (mg/kg of } \\
\text { soil) }\end{array}$ & 99 & 125 & Borax method \\
\hline $\begin{array}{l}\text { Exchangea- } \\
\text { ble } \mathrm{K}(\mathrm{mg} / \mathrm{kg} \\
\text { of soil) }\end{array}$ & 83.3 & 45 & $\begin{array}{l}\text { Using an Atomic } \\
\text { Absorption Spec- } \\
\text { trophotometer }\end{array}$ \\
\hline
\end{tabular}


(Fruit et al. 1996). Fang et al. (2007) have compared the decomposition of corn residues in loam soil and quartz sand. They have observed that plant particles finer than $0.25 \mathrm{~mm}$ decomposed slower than $2.4 \mathrm{~mm}$ fractions in the loam soil, though a similarity has not been observed in the sand. According to them, physical protection of the finer particles $(<0.25 \mathrm{~mm})$ by soil colloids could slower the decomposition of plant materials. The composition of the microbial populations colonizing the fine and coarse residue particle may involve different organisms. It is likely that fungi are relatively more abundant in decomposing of the coarse particle than that of the finer particles, due to the ability of hyphae to colonize the part of the coarse particles which may not be in contact with the soil and water films in pores (Ambus and Jensen 1997).

According to present results, Loamy sand soil (clay $9 \%$ ) showed higher $\mathrm{C}$ mineralization compared to Sandy clay loam soil (clay $28 \%$ ) which is in agreement with Sorensen (1996), who also observed that organic residues decompose more slowly in soils with higher clay contents, especially clays having higher exchange capacities. Clay minerals inhibit mineralization during the first stage of decomposition which could be attributed to a higher protection by clay minerals on microbial biomass and metabolites formed during initial decomposition (Jensen 1994).

Figure 3 shows the cumulative $\mathrm{CO}_{2}-\mathrm{C}(\mathrm{mg} / \mathrm{kg}$ soil) evolution from Sandy clay loam soil and Loamy sand soil amended with various sized particles of Gliricidia leaves. Cumulative $\mathrm{CO}_{2}-\mathrm{C}$ content was found to be significantly $(\mathrm{P} \leq 0.05)$ affected by the texture of soil, though not affected by particle size of Gliricidia leaves (Figure 2). Loamy sand soil treated with particle size $\leq 0.05$ $\mathrm{mm}\left(\mathrm{T}_{2} \mathrm{~S}_{1}\right)$ has shown the highest cumulative $\mathrm{CO}_{2}-$ $\mathrm{C}$ value of $1052 \mathrm{mg} / \mathrm{kg}$ soil.

Microbial biomass and its products formed during the initial stage of decomposition could protect the finer particles from further biodegradation, because of intimate mixing of residues with the soil. This would be the reason attributed to the reduction of $\mathrm{C}$ mineralization after first 14 days of incubation in the present study. According to Fang et al. (2007), clay minerals may exert a blocking effect on decomposition. Particle size of leaves influences the contact of the material with clay and silt particles, which can protect organic materials from microbial attack (Hassink 1997). The low C mineralization observed in Sandy clay loam soil may be due to the physical protection of decomposing organic matter by clay and silt particles.

\section{CONCLUSION}

Carbon mineralization of Gliricidia leaves incorporated into soil was affected by the particle size of leaves as well as the texture of soil. Loamy sand soil treated with finer particles $(\leq 0.5 \mathrm{~mm})$ of Gliricidia leaves resulted in the highest C mineralization. However, applications of the present findings would be recommended after the experiments conducted under field conditions.

\section{REFERENCES}

Ambus P and Jensen ES 1997 Nitrogen mineralization and denitrification as influenced by crop residue particle size. Plant and Soil 197: 261-270.

Anderson JPE 1982. Soil respiration. In: Page AL, Miller RH, Keeney DR (eds.) Methods of soil analysis, Part 2, $2^{\text {nd }}$ edn. (Agronomy monograph no. 09) American Society of Agronomy, and Soil Science Society of America, Madison, Wis. pp 837-871.

Angers DA and Recous S 1997 Decomposition of wheat straw and rye residues as affected by particle size. Plant and Soil 189: 197-203.

Fang M, Motavalli PP, Kremer RJ and Nelson KA 2007 Assessing changes in soil microbial communities and carbon mineralization in $\mathrm{Bt}$ and non-Bt corn residue-amended soils. Applied Soil Ecology. 37: 150-160.

Fruit L, Recous S and Richard G 1996 Organic matter decomposition as a function of soil residues contact: Effect of soil structure and residue particle size. In: Symposium on "Interactions of soil minerals with organic components and microorganisms", Nancy 3-6 September 1996.

Grant RF, Juma NG and McGill WB 1993 Simulation of carbon and nitrogen transformations in soil mineralization. Soil Biology Biochemistry 25 (10):1317-1329.

Hassink J 1997 The capacity of soils to preserve organic $\mathrm{C}$ and $\mathrm{N}$ by their association with clay and silt particles. Plant and Soil 191: 77-87.

Jensen ES 1994 Mineralization-immobilization of nitrogen in soil amended with low $\mathrm{C}$ : ratio plant residues with different particle sizes. Soil Biology and Biochemistry 26: 519-521.

Karlen DL, Mausbach MJ, Doran JW, Cline RG, Harris RF and Schuman GE 1997 Soil quality: A concept, definition, and framework for evaluation. Soil Science Society of America Journal 61: 4-10.

Lal R 2001 Soil degradation by erosion. Land Degradation \& Development 12: 519-539. 
Mapa RB, Somssiri S and Nagarajah S 1998 Soils of the wet zone of Sri Lanka. Special Publication I, Soil Science Society of Sri Lanka.

Myers RJK, Palm CA, Cuevas E and Gunatilleke IUN 1994 Brossard The synchronization of nutrient mineralization and plant nutrient demand. In: Woomer PL, Swift MJ, (eds.) The biological management of tropical soil fertility. Chichester, UK: Wiley-Sayce Publication, pp. 81-116.

Panabokke CR 1980. Handbook of the soils of Sri Lanka. J. soil Sci. Soc. 2: 83-85.

Peter V, Regin R and Soren S 2001 Reduced particle size of plant material does not stimulate decomposition, but affects the microbivorous microfauna. Soil Biology and Biochemistry 33: 1805-1810.

Rodolfi G and Zanchi C 2002 Climate change related to erosion and desertification: 1 . Mediterranean Europe, p 67-86, In: RC Sidle, (ed.) Environmental changes and Geomorphic Hazards in Forests. CABI publishing, Wallingford, UK.

SAS Institute 1988 SAS/STAT user's guide, Release 6.03. SAS Institute, Cary, North Carolina, USA.

Scherr SJ 1999 'Soil Degradation: A Threat to Developing-Country Food Security by 2020'
Food, Agriculture and the Environment Discussion Paper 27. International Food Policy Research Institute (IFPRI), Washington, D.C.

Sørensen P, Ladd JN and Amato M 1996 Microbial assimilation of $14 \mathrm{C}$ of ground and unground plant materials decomposing in a loamy sand and a clay soil. Soil Biology and Biochemistry 28: 1425-1434.

Syers JK 1997 Managing soils for long-term productivity. Philosophical Transactions of the Royal Society of London. Series B, Biological Sciences 352: 1011-1021.

Tiessen H, Cuevas E and Chacon P 1994 The role of soil organic matter in sustaining soil fertility. Nature 371: 783-785.

Vanlauwe B, Diels J, Sanginga N and Merckx R 1997 Residue quality and decomposition: An unsteady relationship. In: Cadisch $G$ and Giller KE (eds.), Driven by Nature: Plant Litter Quality and Decomposition, CAB International, pp. 157- 166.

Yadvinder-Singh, Khind CS and Bijay-Singh 1991 Efficient management of leguminous green manures in wetland rice. Advances in Agronomy 45:136-190.

Young A 1989 Agroforestry for Soil Conservation. $\mathrm{CAB}$ International, Wallingford. 